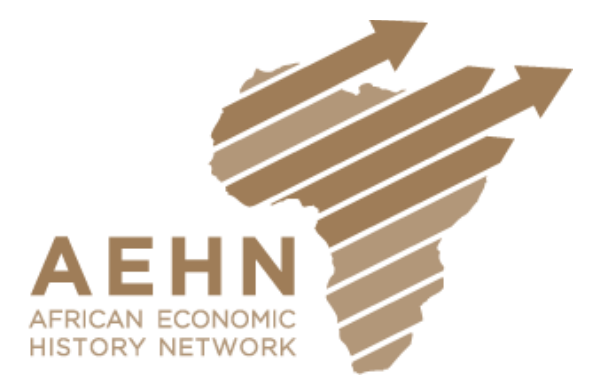

\title{
AFRICAN SOCIALISM; OR THE SEARCH FOR AN INDIGENOUS MODEL OF ECONOMIC DEVELOPMENT?
}

African economic history working paper series

No. 36/2017

Emmanuel Akyeampong, Harvard University

akyeamp@fas.harvard.edu 
ISBN 978-91-981477-9-7

AEHN working papers are circulated for discussion and comment purposes. The papers have not been peer reviewed, but published at the discretion of the AEHN committee.

The African Economic History Network is funded by Riksbankens Jubileumsfond, Sweden

For submissions, contact:

Erik Green

Department of Economic History

Lund University

P. O. Box 7083

Sweden

Erik.Green@ekh.lu.se 


\title{
AFRICAN SOCIALISM; OR THE SEARCH FOR AN INDIGENOUS MODEL OF ECONOMIC DEVELOPMENT?
}

Emmanuel Akyeampong ${ }^{1}$ ?

\begin{abstract}
Ralph Austen in African Economic History (1987) noted how few African countries explicitly choose capitalism on independence, and for those who did it was a default model or a residual pattern. 'African socialism' was popular in the early decades of independence and pursued by several countries, including Ghana, Guinea, Senegal and Tanzania, the cases considered in this paper. The term had multiple meanings, and its advocates were quick to stress that they were not communist, and some said they were not even Marxist. This paper explores the argument that African socialism was a search for an indigenous model of economic development for a generation that was justifiably ambivalent about capitalism, but wary of being put in the communist camp in the Cold War era. Importantly, advocates of African socialism often proposed bold and transformative visions for their countries. These visions might be worth revisiting, devoid of the paradigm of socialism.
\end{abstract}

Keywords: Ghana, Guinea, Senegal, Tanzania, colonialism, independence, industrial policy, agriculture, Soviet Union, capitalism, communism, socialism

JEL code: P20, O21, O55, B24, N17

\section{INTRODUCTION}

On the attainment of independence in the latter part of the 1950s and in the 1960s, African nationalist governments found themselves in an economic quandary. Faced by the huge socioeconomic needs of populations just emerging from colonial rule, these new governments needed nothing short of a 'revolution' to lift their countries out of decades of social, economic and political neglect. In 1960, one of the first cabinet ministers in the Patrice Lumumba government in the independent Congo told Basil Davidson, in his documentary on the rise of African nationalism, Africa (Davidson, 1983), that there were only three college graduates in the Congo on independence.

There were two available economic models: capitalism, and socialism or communism. Capitalism, when explored by these new governments, often smacked of 'neo-colonialism' because, by putting them back in the arms of Western expatriate capital, it would seem to subvert the achievement and purpose of political independence. And in the context of the Cold War, mention of socialism or communism was interpreted as alignment with the Eastern bloc, and with countries like the Soviet Union and China. The recent twentieth-century revolutions of Russia

\footnotetext{
${ }^{1}$ Emmanuel Akyeampong is the Ellen Gurney Professor of History and of African and African American Studies at Harvard University. The author acknowledges the invaluable contributions of his research assistants, Shae Omonijo, University of Chicago, and Serges Saidi, Harvard University. This paper is based on the LEAP (Laboratory for the Economics of Africa's Past) Lecture presented by the author at the University of Stellenbosch on 25 October 2017.
} 
and China had given their imprint to the concept of 'revolution', obscuring the transformative effect of revolutions in nation-building as evidenced by the eighteenth-century revolutions in the US, France and Haiti. Striking out in a bid for economic self-reliance, African nationalists coined the term 'African socialism', which seems to hold different meanings for its advocates. Yet its adherents, when placed in the camp of the Soviet Union or China by the West, protested their discomfort.

This paper explores the perception that African socialism was at its roots a search for an indigenous model of economic development that would be revolutionary both in time and scale. A close reading of the writings of some of its key advocates, such as Senegal's Leopold Senghor or Tanzania's Julius Nyerere, shows they were not ignorant of Marxist theory. Indeed, one of the best expositions of the thought and works of Marx and Engels that I have read is Senghor's On African Socialism (Senghor 1964). That the emphasis in African socialism varied for its various advocates perhaps reflects the unique circumstances of each new nation's challenges. These leaders believed that while Marxism was an important method, it needed to be modified for the African context, where industrialization was absent, urbanization minor, class struggle was not the driver of history, and religion was an important aspect of lived realities. Socialism was a method with an ethic of egalitarianism that could be grounded in African history and culture, hence the term 'African socialism'. President John F. Kennedy was perceptive in discerning after meeting several of Africa's new leaders that they were at heart nationalists and not communists, and that their desire and intent was to develop their countries. Elizabeth Schmidt has noted that: 'Radical nationalism was frequently confused with communism - or viewed as an equal threat to Western interests. Fear of communism - real or imagined - led the U.S. government to support many unsavory dictatorships' (Schmidt 2013: 24). After meeting Ahmed Sekou Touré in 1961, Kennedy instructed the US Agency for International Development (USAID) to put together a modest aid programme for Guinea and asked Sekou Touré to desist from his socialist rhetoric.

In this paper I explore the pursuit of African socialism and its intent by Ghana under Kwame Nkrumah, Guinea under Sekou Touré, Senegal under Senghor, and Tanzania under Nyerere, four instructive careers seldom analysed together today. ${ }^{2}$ My focus is on the economics of the paradigm, though it is difficult to separate economics and politics, as socialism is an approach to political economy. Several works exploring African socialism were published in the 1960s and 1970s, including some by the architects of the concept (Brockway 1963; Senghor 1964; Onuoha 1965; Nyerere 1968; Babu 1981). The 1980s put paid to the concept and the vision, as steep economic decline resulted in what has been called Africa's 'lost decade'; the most notable architect of African socialism, Nyerere, conceded that his attempt at ujamaa had failed and stepped down from power in 1985; and the collapse of the Soviet Union in 1989 marked the triumph and ascendancy of capitalism. It is only more recently that a few works have revisited the vision and practice of African socialism, but these have been single country studies. ${ }^{3}$ It is clear that economic development has remained elusive in Africa. That many of the economic and social challenges that inspired the concept of African socialism remain with us cannot be denied. Is there merit in revisiting what was envisioned in African socialism, not with the aim of resurrecting it as a practice or an economic model, but of re-engaging the desire for broad transformative change, especially as commentators have observed that the bold future its architects envisioned has not been achieved by subsequent governments? ${ }^{4}$ Can we throw out the bathwater and keep the baby,

2 There are important exceptions. See, for example, from an earlier period, Friedland \& Rosberg (1964) and Mohiddin (1981), and more recently Assensoh (1998), though an interrogation of African socialism was not Assensoh's explicit agenda.

${ }^{3}$ See for example Lal (2015) and Williams (2016).

${ }^{4}$ A question asked in the case of Nkrumah and Ghana by Asamoah (2014: 79). 
the dream of rapid socio-economic change that would leave no one behind?

\section{IMMEDIATE HISTORICAL BACKGROUND AND INTELLECTUAL INFLUENCES}

Whereas 'vision' speaks to intent, 'agenda' is a plan of action, and Africa's new leaders needed a developmental agenda to lift their citizens out of poverty and illiteracy. There was a huge dearth of human and financial capital. Very little physical infrastructure existed in African colonies outside of settler colonies, and the little that existed was designed for the extraction and export of natural resources and not for the cohesive, integrated growth of national economies (Akyeampong 2015). Former President Jakaya Kikwete of Tanzania said in an interview in 2017 that Tanzania on independence had only three medical doctors and two engineers. ${ }^{5}$ As these examples illustrate, many African nationalist governments inherited or assumed the economic agendas of their former colonial rulers.

In the aftermath of World War II, the colonial state became a developmental state, as it sought to develop colonial economies to the benefit of the metropole. This period has been described as the 'second colonial occupation', marked by a technocratic bent to colonialism as colonial officers promoted a revolution in agricultural practices, introduced mechanization and irrigation, explored new sources of energy, and laid the foundation for the first wave of import-substitution industries. Their vision required infrastructural development that would provide the electric power for manufacturing and put in place a transport system that would integrate the colonial economy more cohesively. Out of this endeavour was born development economics, which first operated under the name 'colonial economics', as it focused on the economic development of tropical colonies. This new emphasis in late colonial rule explains why several of the early African nationalist governments adopted the economic policies of this period. Pioneers in development economics included prominent economists like the West Indian William Arthur Lewis, who was trained at the London School of Economics and worked as a consultant in the Colonial Office during World War II. His work at the Colonial Office and his growing knowledge of the colonial economies of Latin America, Asia and Africa led him to revise central assumptions of neoclassical economics. In the developing world, where poverty was deep-seated, resources limited, populations growing rapidly and an indigenous middle class non-existent, Lewis concluded that the state would have to assume a central role in driving economic growth. State leadership and centralized planning, together with lessons learned from Keynes in the great depression, such as state spending on infrastructure as a way of stimulating production and consumption, all came to inform development economics. Industrialization was assigned a primary role, and Lewis's articles, especially Economic Development with Unlimited Supplies of Labour (Lewis 1954), gave, in the words of his biographer Robert Tignor, 'an aura of inevitability' to economic growth once processes he had outlined were followed (Tignor 2006: 95). Lewis was a Fabian socialist, and several of Africa's leaders in the 1930s and the 1940s had encountered Fabianism as students in the UK. Benno Ndulu observes that: 'The most prominent among the first-generation African leaders (for example, Nkrumah, Nyerere, Kaunda, Kenyatta, Senghor, Ramgoolam) espoused the Fabian socialism intellectual tradition as well as ideology' (Ndulu 2008: 325). The influences on African socialism were complex.

This reformist drive after World War II overlapped with the beginnings of the Cold War, and

${ }^{5}$ Interview with former President Kikwete, Cambridge, MA, 29 March 2017. In an interview published in 1994, Nyerere provided different figures of 13 medical doctors and two trained engineers (Meldrum 1994: 70-72). 
European colonial powers sought to convince the US that the colonies were essential to their capacity to counter Soviet designs on the developing world. American support for Western Europe, through policies such as the Marshall Plan, gave new life to empire. As Philip Muehlenbeck has noted, the Eisenhower administration's Africa policy was 'little more than an extension of the Marshall Plan predicated upon ensuring that African resources remained accessible for Western Europe's recovery from World War II’ (Muehlenbeck 2012: 4). American scholars in the social sciences, with the financial support of government and private institutions, were also developing a framework that would enable the US to engage the newly independent and decolonizing countries in Latin America, Asia and Africa. This impetus gained momentum when Kennedy became president in 1961, under the framework of 'modernization theory', America's blueprint for economic prosperity in an industrialized society and a bulwark against Soviet communism. Several of the American social scientists at the forefront of modernization theory, who included Daniel Lerner, David Apter and Samuel Huntington, studied the Third World. Kennedy invited the distinguished MIT economist Walt Rostow to join his national security council and lead the agenda of modernization. Rostow launched the 'Kennedy Development Decade', whose policy goal was to 'help other countries learn how to grow' (Muehlenbeck 2012: 48). Rostow's work prescribed the stages of economic growth and outlined what needed to be done to move from subsistence to market economies. The very title of his 1964 book, The Stages of Economic Growth: A Non-Communist Manifesto, underscored the context and contest of the Cold War (Rostow 1964).

But the narrative of modernization was complicated, for not only capitalist societies could lay claim to having modernized economies. Nils Gilman notes that: 'To explain how the Soviet Union could be both the same ("modern") and different from the US ("the West"), modernization theory described Communism as a "pathological" or "deviant" form of modernity, always hoping that the Soviets would "converge" with the liberal version of modernity extant in the West' (Gilman 2003: 14). Instructively, both modernization theory and communism believed in industrialization, large-scale infrastructure projects, and the transformation of agriculture (Scott, 1998). The Kennedy government from 1961 moved away from Eisenhower's policy position on Africa, which was essentially to ally with European colonizers and white settlers, based on Secretary of State John Foster Dulles's perception that Third World nationalism was a Soviet creation and claims that Cold War neutrality or non-alignment was only in reality a 'transitional stage to Communism' (Muehlenbeck 2012: 3-4). In place of this, Kennedy forged an African policy based on four principles: opposition to European colonial rule, acceptance of African non-alignment, the offer of economic development packages to African countries, and a new period of personal diplomacy (Muehlenbeck 2012: 44). This nuanced position explains enigmatic developments in early independent Africa, such as the World Bank's design and support of Tanzania's early 'villagization' scheme.

\section{THE CHALLENGES AT INDEPENDENCE}

The first wave of African independence was achieved from the mid-1950s: Sudan became independent in 1956, followed by Ghana in 1957, and then a slew of Francophone states and Nigeria in 1960. The pace continued, as each year witnessed the lowering of colonial flags and the raising of flags of new African independent states. 'Development' was the primary challenge and objective of the new states. By this was meant an improved standard of life represented by key indicators such as better access to housing, health, education and jobs. Many of the new nation-states seemed ill-prepared for this gargantuan challenge. In Guinea, the capital city of Conakry attained notoriety by its famous 'no' vote in the 1958 referendum on the new French 
Community. France retaliated by withdrawing financial and material support, and French officials as they left stripped Guinea of records, equipment and anything that could be moved, and destroyed what could not be moved. Even telephone lines were cut. Guinea became independent on 2 October 1958. It was Nkrumah's loan of 10 million pounds sterling in late November 1958 - after Ghana and Guinea had entered into a vaguely defined union - that prevented Guinea's collapse (Kaba 2017: 93). With all its records destroyed, Guinea did not even have a baseline from which to plan economically. Guinea's president, Sekou Touré, a trade unionist who had been tagged by the American intelligence agencies from the early 1950s as a communist, told William Attwood, America's first ambassador to Guinea, that Guinea was so poor that it could not be concerned with ideology, only action (Muehlenbeck 2012: 62). As late as $1994-5$, 85\% of the employed workforce in Guinea had no formal education at all, $7.3 \%$ had only primary education, $4.5 \%$ had secondary education, and just over $1 \%$ had professional training or higher education. In 2001 , only $10 \%$ of Guinea's roads were surfaced, and only $0.8 \%$ of its rural population had access to electricity (Doumbouya \& Camara 2008: 600, 608-9).

Tanganyika when it became independent in 1961 was a very rural and poor country. I have already mentioned the number of doctors and engineers at independence. Nyerere declared on independence that the government had three development problems: poverty, disease and ignorance. Since the country was largely rural, rural development would take priority. Nyerere often said that Tanzania had land and not money, so its development programmes would have to be land-oriented, since to privilege a development agenda based on money would of necessity mean privileging foreign aid and investment. As Tanzania was a nation of village communities, many scattered, to deliver social services that would improve the lives of Tanzanians Nyerere advocated more aggregated settlements or 'villagization'. This would facilitate the provision of education, health facilities, clean water and other social amenities (Shivji 2010: 120-33). Tanzania launched its first three-year plan from 1961 to 1963 with the assistance of the World Bank. Tanzanian professor of law Issa Shivji writes of this stage:

The heart of the World Bank's villagization programme was the modernization theory which was rampant at that time. Traditional peasants had to be pulled into and integrated in the international commodity circuits. The programme was based on the so-called transformation and improvement approach. Model farmers would be settled in villages, given modern technology and they would farm under the supervision of managers. (Shivji 2010: 121)

This programme of villagization left untouched the structures of Tanzania's colonial economy, which exported primary materials and imported manufactured items. At this stage villagization was not so much a model of economic development as a means of providing social services. For various reasons, villagization was a colossal failure (Shivji 2010: 121-22). Tanzania's economy remained open to foreign investment, and capital formation increased between 1963 and 1967 with an income growth rate per capita of about $4.1 \%$ in those four years (Mwase \& Ndulu 2008).

But Nyerere was dissatisfied. Tanzanian economists Nkunde Mwase and Benno Ndulu explain:

The government was not content with the speed of industrial growth and the extent to which indigenous ordinary Tanzanians were benefiting from independence. It highlighted the dangers of being trapped in a dependent capitalist development which offered nothing but increased alienation for the peasant majority. The government was concerned about Tanzania's continued high external dependence, particularly in the light of evidence indicating increasing manufacturing capacity in neighboring countries. It was argued that, following independence, a dependent but growing African capitalist class had emerged, creating a potential for a dynamic coalition of this elite group with foreign capitalists and hence perpetuating the dependence on the 
former colonial powers. (Mwase \& Ndulu 2008: 431)

Nyerere believed that Tanzania, in its infatuation with modernization theory, had put too much emphasis on industrialization because of its misperception that without industry there is no development. This was a mistake, as Tanzania had neither the capital nor the technical expertise to drive industry. And in its quest for industry it had focused on urban areas to the neglect of rural areas, whereas most Tanzanians lived in villages. In 1967 Nyerere and his ruling Tanzania African National Union passed the Arusha Declaration and Tanzania embarked on an explicitly socialist developmental path with a focus on agriculture and self-reliance (Nyerere 1968: ch. 2).

None of the black African nation-states had an indigenous capitalist class. This, perhaps, would have been a contradiction under the colonial dispensation. It was clear that the state would have to play a central role in economic development. That foreign investment would play a crucial role was evident, but states that had just come out of colonialism were justifiably wary of foreign capital from Western Europe. This was too close to the immediate colonial past, and threatened to be what Nkrumah called 'neo-colonialism'. Key ideals, such as 'positive neutralism' for Nkrumah during the Cold War era, or 'self-reliance' for Nyerere, came to define fervent desires that would inform new economic models. Capitalism with its trickle-down economics would not bring the rapid transformation desired by new nations with huge needs. Socialism or communism would put them in the Soviet or Eastern camp, which came with its liabilities. The new African nations claimed they were non-aligned, taking their inspiration from the Bandung movement of 1955. They insisted on the freedom to be associated with both the West and the East without being labelled ideologically. Africa's new leaders were attracted to the US because of its ability to customize aid programmes for the specific needs of each country. Aid from the Soviet Union tended to be inflexible, often coming in the form of military aid or Soviet and Eastern European products bartered for African goods - goods that were often useless to the Africans, the Soviet gift of snowploughs to Guinea being a notable example (Muehlenbeck 2012: 112). Africa's new leaders turned to the US, which had not held colonies in Africa, and astute American politicians like Kennedy discerned that these leaders were more nationalists than ideologues. And Africa's leaders were not above playing both sides, as they noted that the US paid more attention to countries that insisted on remaining friendly with the two camps.

Ghana and Senegal were in stronger economic positions than Guinea and Tanzania. But still the level of need was high for these countries emerging from colonial rule. Nkrumah's Convention People's Party had convincingly won the first general elections in Ghana in 1951 and acceded to internal self-government after a second electoral win in 1954. Ghana was one of the wealthy British colonies with significant revenues from cocoa, mining (especially gold) and timber. But the biggest revenue was from cocoa, and the nationalist government under Nkrumah sought to diversify the economy to avoid this undue dependence on a single commodity. From World War II, the British had created a marketing board which pegged the price of cocoa below the world market price, to create a fund that would stabilize cocoa in the years when the world market price dropped below the price offered locally to cocoa farmers. In 1952 Nkrumah invited the economist Lewis to prepare a report on how Ghana could industrialize. The result was Lewis's Report on Industrialization and the Gold Coast (Lewis 1953). In the Caribbean and Asia, with their large populations, Lewis had advocated industrialization as a development strategy, but for Ghana with its small population and land resources he advised a focus on agricultural improvement and strengthening of food production. He recommended a small range of light import-substitution industries to be funded by foreign investment and advised the Ghanaian government to invest its resources in agriculture. Ghana's nationalist politicians were astounded (Tignor 2006: 122-124).

The advice was unacceptable to the ambitious Nkrumah, who was determined that black Africa's 
first independent nation would be a shining star for Africa and beyond. He persisted in his vision of an industrialized nation but struggled to attract investment between 1957 and 1960. Between the years of Ghana's formal independence and when it became a republic, the country switched increasingly to a socialist policy and to state-led development through state-owned industries. The centrepiece of Nkrumah's development strategy was the Volta River Project and the expectation that the cheap electricity that would be generated by the Akosombo Dam would drive the state's industries. Lewis, who had joined Nkrumah as his chief economic advisor on independence, painstakingly pointed out that cheap electricity would not necessarily be the key to the country's industrialization. Their disagreements about the value of the Volta River Project in the overall development scheme and its cost, and about many other industrial projects that Nkrumah desired and Lewis considered economically unproductive, led Lewis to resign his position at the end of 1958 and leave Ghana. Lewis’s five-year development plan for the period 1959 to 1964 was scrapped in 1962, and the Nkrumah government began to plan a socialist development plan, which it launched in 1964. Nkrumah's unbending commitment to the Volta River Project fitted into the paradigm of modernization and the penchant for large-scale hydro-electric schemes. But Tignor observes that

Nkrumah's interest in Volta was not mere political showmanship and personal ambition. It, too, drew upon a body of economic writing that looked with approval on TVA-like [Tennessee Valley Authority] hydroelectric schemes and argued that large-scale hydroelectric schemes had the potential to produce far-reaching economic benefits. By generating cheap power supplies, they would spur industrial development and create diversification. (Tignor 2006: 200-1)

Nkrumah was overthrown in a military coup in February 1966, barely a month after the Akosombo Dam was commissioned, so it is impossible to know what uses he would have made of Ghana's electricity. But he left a record of socialist-inspired, state-led industrialization between 1960 and 1966.

Senghor's Senegal had been the capital of the French West African Federation. In this capacity it was the heir to federal institutions of governance and education and an extensive infrastructure of industry and commerce. Federation had provided economies of scale for Senegal's industries based on groundnut oil, fish products, other food industries and textiles, and a primary concern for Senghor was how to secure markets for Senegal's industries with the break-up of the federation and the pursuit of industrialization by the component states (Ndiaye 2008: 401-25). Senegal's population comprised about $80 \%$ peasants. Groundnuts were the major export. As a poet, Senghor had been one of the founding fathers of négritude, an artistic and cultural movement which he viewed as Africa's contribution to world culture. As president of Senegal, he sought to merge négritude with socialism to create his version of African socialism, a 'democratic socialism' which he viewed as the engine for developing a sense of nationhood among the multiple ethnic and social groups and for pursuing political, economic and cultural reforms which would improve the standard of living for the masses (Senghor 1964). Senghor's developmental agenda for his new nation combined African socialism with continued cooperation with France, but on a basis of equality and an abiding commitment to federalism, as evidenced by Senegal's continual attempts to be part of larger political entities, from the brief Federation of Mali, which lasted from January 1959 to August 1960, to the post-Senghor experiment of the Senegambia Confederation from 1982 to 1989.

African socialism became an important model of economic development for countries like Ghana, Guinea, Senegal and Tanzania. But the model looked different in each case, with the common thread being the desire for political and economic autonomy, self-reliance, the Africanization of business and the civil service, pan-Africanism, and non-alignment. The US closely followed 
political and economic developments in the newly independent African states, monitoring Soviet influence and investments from the Eastern bloc. It listened keenly to rhetoric, trying to discern political alignment through what Africa's new leaders said. Kennedy was persuaded that a modest economic aid package for Guinea would change Sekou Touré's socialist rhetoric. Nyerere was seen as a person of principle and integrity, and, interestingly, his socialist experiment received significant aid from Western countries. Nkrumah took exception in 1960, when the US Secretary of State, Christian Herter, described him as leaning towards the Soviet camp. But Nkrumah's politics, and his support of liberation movements and opposition groups from newly independent countries, alienated even neighbours like the Ivory Coast, Togo and Nigeria. Many African leaders felt Nkrumah could not be trusted. And at home he became dictatorial. A CIA report of 17 April 1963 said: 'Ghana's vain and egocentric Kwame Nkrumah is driven by his dreams of primacy in a united Africa and of a world role as a leading figure among the nonaligned states.' ${ }^{6}$ Senghor, despite his profession of African socialism, maintained ties to France and the European common market, enabling Senegal to mobilize substantial external resources that postponed the need for structural change in an under-performing economy (Ndiaye 2008: 421).

All four of these leaders, Ghana’s Nkrumah, Guinea’s Sekou Touré, Senegal's Senghor and Tanzania's Nyerere, professed 'African socialism'. And though their African socialism shared commonalities, there were also important differences. These attempts at African socialism, Mercer Cook points out, were 'bitter gall to the communists, who are taught to take their Marxism straight, without ice cube or aspirin' (Senghor 1964: xi-xii). But these leaders insisted on having not only their socialism but an African socialism. The next section explores the experiment and the record of African socialism in the four countries.

\section{AFRICAN SOCIALISM TO THE RESCUE}

We are fortunate that all four statesmen were writers who put their philosophies and visions for their new nations on record. There are some common threads to their philosophical reflections on African socialism. All viewed their ideological positions as central to nation-building, and ideological education as essential for welding together new nations from disparate ethnic groups and instilling patriotism. All viewed the independence of their countries as connected to the broader movement to liberate the entire continent from colonial rule. All emphasized a revival of the cultural values of an African past, but in ways that positioned them for the contemporary world. All valued economic self-reliance and non-alignment. But whereas Nkrumah, Senghor and Nyerere had encountered leftist ideologies when they were students in Europe or the US, Sekou Touré's rise was as a trade unionist and he was looked down on by the intellectuals within the African Democratic Rally (RDA), the pan-regional political party in French West Africa, because he held only a certificat d'études (Schmidt 2007: 129). Indeed, Sekou Touré seems not to have had a leftist agenda until he was urged in that direction by the young radicals in his country, especially those who had been educated in France. As late as July 1958, Sekou Touré kept pushing for a revision of the constitution and not for independence (Schmidt 2007: 144).

In his book on the cultural revolution, written to outline the beliefs, vision and plan of the Parti démocratique de Guinée, Sekou Touré states that the cultural revolution is a socialist view that places the improvement of society above individual interest. Colonialism, he said, was an act of

${ }^{6}$ CIA Files, OCI No. 1359/63. Current Intelligence Memorandum. Subject: Orientation of Nkrumah Regime, April 17, 1963. Approved for release March 7, 2007. ${ }^{8}$ Nyerere was known by the Swahili honorific mwalimu ('teacher'), his profession before he entered politics. 
cultural aggression:

All imperialism is always accompanied by a cultural aggression, an acculturation enterprise, an action of cultural alienation for the purposes of a complete conditioning, necessary for a political and economic subjugation. And this is why, for peoples emerging from colonial enslavement, the task of cultural dis-alienation for the return to national culture is imperative for the consolidation of national independence and concrete sovereignty, meaning the full exercise of the popular will in all fields. (Sekou Touré 1972: 117)

For Sekou Touré this was not a return to some romantic past. He saw culture as dynamic and he underscored the rationality of the Guinean people in discerning what is right. This led him to disagree with Senghor's négritude, which viewed Africa's contribution to world culture as emotional and spiritual, while Europe's contribution was through critical thinking. ${ }^{7}$ Unlike Senghor, who sought some union of African and French culture, understandable for someone married to a French woman, Sekou Touré even advocated a return to African languages. Considering that France had ended its presence in Guinea after Conakry's 'no' vote, Sekou Touré's position is understandable.

Senghor, on the other hand, was erudite, a product of the Sorbonne and the first black African to attain the distinction of agrégé, the highest teaching diploma in France. This erudition shines powerfully in his On African Socialism, an intellectual tour de force. He reflected on the parting of ways in 1948 between Senegalese nationalists and the French Socialist Party after the Africans came to appreciate that French workers together with the bourgeoisie were beneficiaries of colonial rule, and that colonialism and the class struggle did not necessarily align. Senghor declared:

We are not 'Marxists' in the sense given the word today, in so far as Marxism is presented as atheistic metaphysics, a total and totalitarian view of the world, a weltanschauung. Marx himself once said: 'As for me, I am not a Marxist.' We are socialists. In other words, we shall exclude neither Marx nor Engels from our sources; we shall start from their works as from those of the 'utopian socialists', and we shall add to these sources the works of their successors and commentators. But we shall retain only the method and the ideas: the method, to help us to analyze our situation; the ideas, to help us to solve our problems. (Senghor 1964: 26)

Senghor rightly points out that Marx was a philosopher who became interested in economics because of his interest in the conditions of the European working class. He states, accurately, that: 'We must not consider Marx as an economist like Keynes, but as a sociologist, a philosopher' (Senghor 1964: 33). He clarifies further: 'We are not Communists', and offers theoretical and practical reasons why not. And just in case the West thought they had a convert in the making, he affirms: 'Nevertheless, we shall not be won over to a regime of literal capitalism and free enterprise. We cannot close our eyes to segregation, although the Federal Government combats it, nor can we accept material success as a way of life.' He pronounces: 'We stand for a middle course, for a democratic socialism, which goes so far as to integrate spiritual values, a socialism which ties in with the old ethical current of the French socialists' (Senghor 1964: 46).

Of our two highly educated English speakers, Nkrumah and Nyerere, Issa Shivji notes that the latter was not a theorist, pointing to the 'virtual absence of his theorizing village development as charting out a new path of development' (Shivji 2010: 123). Nyerere just wanted to see the

\footnotetext{
${ }^{8}$ Nyerere was known by the Swahili honorific mwalimu ('teacher'), his profession before he entered
} politics. 
standard of living rise for Tanzanians. He was uncomfortable about the accumulation of wealth, whether by urban workers and entrepreneurs or rural peasants. Shivji continues:

Mwalimu's thought did not capture the political economy aspect of his central emphasis on the village. ${ }^{8}$ I would dare suggest that this is because Mwalimu, unlike, for example, Nkrumah, did not fully understand or appreciate the political economy of imperialism. As is well known, he never accepted that building socialism was a process of class struggle. He did not therefore accept that the state he was leader of had a class character. He believed that the state could carry out the reforms he genuinely believed in so long as it had a selfless, committed leadership. (Shivji 2010: 132)

Nyerere naively believed that if he could prevent accumulation in rural and urban Tanzania, he could avert the formation of classes and the concomitant class struggle that had torn European society apart.

In this respect Nyerere was a better historian of Europe than he was of Africa, as he outlined the historical processes that had created capitalism in Europe, and why the foundations of socialism in Africa were different:

European socialism was born of the Agrarian Revolution and the Industrial Revolution which followed it. The former created the 'landed' and the 'landless' classes in society; the latter produced the modern capitalist and the industrial proletariat. These two revolutions planted the seeds of conflict within society, but its apostles sanctified the conflict itself into a philosophy. (Nyerere 1968: 11)

On the contrary, he said, the foundations of African socialism lay in the extended family: “"Ujamaa”, then, or "Familyhood”, describes our socialism.' He said African socialism was opposed to capitalism and doctrinaire socialism, the first based on exploitation of man by man, the second on the ‘inevitable conflict between man and man’ (Nyerere 1968: 12).

Nkrumah believed in the dialectical method, and how it shed light on the process of decolonization and development, but he was not an atheist. He was a philosopher with an understanding of economics, and the primary work expounding the philosophy behind his approach to African socialism is his book Consciencism, published in $1964 .{ }^{9}$ Here is his explanation of 'consciencism':

Social revolution must therefore have, standing firmly behind it, an intellectual revolution, a revolution in which our thinking and philosophy are directed towards the redemption of our society. Our philosophy must find its weapons in the environment and living conditions and the intellectual content of our philosophy must be created. The emancipation of the African continent is the emancipation of man. This requires two aims: first, the restitution of egalitarianism of human society, and, second, the logistic mobilization of all our resources towards the attainment of that restitution.

The philosophy that must stand behind this social revolution is that which I have once referred to

${ }^{8}$ Nyerere was known by the Swahili honorific mwalimu ('teacher'), his profession before he entered politics.

${ }^{9}$ Nkrumah obtained two Bachelors degrees from Lincoln University, in Economics and Sociology (1939) and Theology (1942), and two Masters degrees from the University of Pennsylvania, in Education (1942) and Philosophy (1943). 
as philosophical consciencism; consciencism is the map in intellectual terms of the disposition of forces which will enable African society to digest the Western and the Islamic and the EuroChristian elements in Africa, and develop them in such a way that they fit into the African personality. The African personality is itself defined by the cluster of humanist principles which underlie the traditional African society. Philosophical consciencism is that philosophical standpoint which, taking its start from the present content of the African conscience, indicates the way in which progress is forged out of the conflict in that conscience. Its basis is in materialism. (Nkrumah 1970 [1964]): 78-79)

Not many of Nkrumah's followers understood his philosophy, which over time came to be referred to as 'Nkrumahism'. Kofi Baako, the Minister of Presidential Affairs under Nkrumah's government, provided a more succinct definition of 'Nkrumahism' as a 'non-atheistic scientific socialism modelled on African conditions' (Asamoah 2014: 57). The CIA was dismissive of Nkrumah's ideological positioning, saying that 'while he has a strong affinity for socialist doctrines, as adapted to the African milieu, he is primarily concerned with advancing his own designs'. ${ }^{10}$

Having provided brief synopses of what lay at the core of the African socialist tenets of our four leaders, I now turn to how their economies fared under African socialism. All four leaders developed economic control regimes where the state and not the market determined economic conditions. And the economies of all four countries fared badly under African socialism. Nkrumah was the first of the four leaders to be evicted, through a military coup in February 1966. But by 1961 the Ghanaian economy was already in trouble, as a CIA memorandum explained:

Nkrumah's troubles are compounded by economic difficulties. World cocoa prices are at the lowest level in years, and cocoa farmers are further irritated by the allocation of Marketing Board funds to general economic development plans rather than the alleviation of their special difficulties. Moreover, even the broader economic programs have misfired to the point that in the four years since independence the government has squandered a financial patrimony of £250 million through ill-advised development schemes and the consultation [sic - construction?] of pre-possessing government buildings, and lavish living by officials. ... Current indications are that Ghana's reserves will have run out by 1962 and that the Nkrumah government will be in desperate need of budgetary support from abroad, as well as financial aid for existing development programs. ${ }^{11}$

Despite his profession of socialism and his leanings towards the Eastern Bloc from 1960, Nkrumah did not nationalize foreign businesses, unlike his friend Gamal Abdel Nasser of Egypt, who by 1961 had nationalized 593 businesses to reshape Egypt's economy (Asamoah 2014: 73). What Nkrumah did was to use the Eastern bloc countries in his endeavour to expand the Ghanaian economy by establishing state-owned enterprises. In 1962 the Ghanaian newspaper the Daily Graphic published a gazette notice saying that 'in the sixty-three agreements signed in 1961 with foreign governments; forty-four were with East European countries on trade and payments as well as scientific, technical, and cultural co-operation; five were with China; five were with Yugoslavia; and one was with the United States, on the operation of the Peace Corps' (Asamoah 2014: 77).

${ }^{10}$ CIA Files, OCI No. 1359/63. Current Intelligence Memorandum. Subject: Orientation of Nkrumah Regime, April 17, 1963.

${ }^{11}$ CIA Files, CIA Office of National Estimates. Memorandum for the Director. Subject: The Situation in Ghana. July 24, 1961. 
The government statistician E. N. Omaboe, in a 1966 study, noted that though the Nkrumah government had invested heavily in the public sector and state-owned enterprises, the impact was yet to be felt. Trade with the Eastern bloc also remained small: in 1963 only 11\% of Ghana's imports came from the bloc and 13.7\% of its exports went to the bloc (Omaboe 1966: 29-31). A more recent study has noted that the state-owned enterprises performed badly, and that by 1966 these numbered about 52, in addition to 25 industrial and manufacturing concerns (Asamoah 2014: 75). Ghana's external reserve deteriorated sharply between independence in 1957 and Nkrumah's overthrow in 1966, falling from \$269 million to a negative \$391 million. In short, by the time of Nkrumah's overthrow, Ghana was bankrupt (Aryeetey \& Fosu, 2008: 297).

Guinea, the country that had forged a union with Ghana in 1958, did not fare any better, though Sekou Touré did serve as head of state until his death in 1984. Guinea provided refuge for Nkrumah on his overthrow, and Sekou Touré appointed Nkrumah co-president. Guinea's economy on independence was based on banana plantations and the mining of gold, diamonds, bauxite and iron. In 1961, when Kennedy became president, he approved an aid programme for Guinea despite the protestations of French President Charles de Gaulle:

It was agreed that Guinea would be offered the construction of a dam on the Konkouré River that was capable of providing power for light industry, staffing for an English-language teaching programme, food aid, a training programme for Guinean administrative and technical personnel involved in industry and government, and a Peace Corps contingent. (Muehlenbeck 2012: 63)

Sekou Touré gladly accepted the offer. And he proved that he was not an ideologue: during the Cuban Missile Crisis, at the request of Kennedy, he denied the Russians permission to refuel their aircraft en route to Cuba (Muehlenbeck 2012: 69). In this early period of independence, until the end of 1963, Guinea's economy was marked by a regime of soft government control. The state's policy then changed to one of hard control, as state planning replaced the market (Doumbouya \& Camara 2008: 591). Whether the assassination of Kennedy in 1963 influenced this turn is an interesting question. On being informed of Kennedy's death, Sekou Touré lamented: 'I have lost my only true friend in the outside world' (Muehlenbeck 2012: 227). From 1964 to 1984 Guinea switched to a socialist approach to its economy. The state marketed agricultural produce, and farmers were required to deliver a part of their produce to state shops. The state also set the producer prices. In 1982, with its economy in crisis, Guinea became a ward of the World Bank and the IMF and adopted a structural adjustment programme (Doumbouya \& Camara 2008: 5917).

Senegal's economy under Senghor also struggled, as the state adopted protectionist policies in the interest of manufacturing companies that had lost their access to the market of a federated French West Africa on independence in 1960. Assured of a captive market under colonial rule, industries in Senegal seemed unable to think beyond the constructs of the colonial economy. As a resourcescarce country, Senegal's major assets were the institutions it had inherited through its status as a federal capital under French colonial rule. From the 1960s Sahelian droughts and increasing desiccation undermined the viability of Senegal's groundnut industry. Senegal's per capita income grew at an annual rate of $2.9 \%$ between 1960 and 2000, with the population growing at $3 \%$. Ndiaye sums up the economic policies and the results under Senghor, who stepped down from the presidency on 31 December 1980:

A study of Senegal's growth record between 1960 and 1993 reveals the dramatic impact of poor policy choices - notably a 'soft' control syndrome and an episode of unsustainable spending that resulted in heavy market control, a poor investment environment, a large and inefficient government sector, a high level of trade protection, and an unsustainable debt strategy. To make 
matters worse, economic performance was badly hit by adverse climatic conditions, especially droughts, and declining world prices for the country’s main exports. (Ndiaye 2008: 403)

The government not only interfered in manufacturing; it was dependent on rents from the agricultural sector to underwrite the huge increase in the civil service from 34,900 in 1965 to 61,000 in 1973 (Ndiaye 2008: 420). True to Senghor's commitment to a partnership with French capital, foreign businesses were not nationalized in Senegal, and Senegal's membership of the CFA franc zone and its closeness to France guaranteed it external funding and protected it from devaluations until 1994, when France devalued the CFA franc by 50\%.

Tanzania underwent one of the major economic transformations in the history of independent Africa when the government's 'Operation Vijiji' forced nine million peasants to relocate to development villages within a period of four to five years. The government resorted to compulsion when it became evident that peasants were not interested in communal production. About $70 \%$ of the Tanzanian population had relocated by 1975 (Nyerere 1977: 41-42; Shivji 2010: 122-3). In the Arusha Declaration of 1967 the government had announced its intention to nationalize industries. When Nyerere took stock of the Tanzanian economy in 1977, he admitted honestly that the economy had done badly both in agriculture and industry. He conceded that 'the truth is that the agriculture results have been very disappointing' and that: “Almost all our industrial plants are running well below capacity; sometimes less than $50 \%$ of what could be produced with existing machinery is actually being manufactured and put to the market' (Nyerere 1977: 19, 33). The economists Mwase and Ndulu provide the reasons for this dismal failure:

The egalitarian undertones in government policy-making resulted in the subordination of economic incentives to political objectives. Economic policy-making during the 1970s and early 1980s was designed to support the political goal of achieving equity at the interpersonal, interregional, and rural-urban levels. (Mwase \& Ndulu 2008: 427)

By the late 1970s ujamaa had been abandoned. There was no incentive for peasants to exert themselves when they did not reap the rewards of their labour.

Strikingly, unlike Ghana under Nkrumah, which was penalized by the Western donor community for Nkrumah's socialist policies, Tanzania received copious donor money throughout Nyerere's period in government. I argue that the international donor community could see that Tanzania was genuinely in search of an indigenous economic model, and though they may have disagreed with Nyerere's policies, they respected the sincerity of his endeavour and his integrity. Mwase and Ndulu comment that:

It is quite striking that even the 'hard control' phase of Tanzania's development received quite strong endorsement by development partners, as evidenced by the large inflows of aid and official credit to fund the country's communist programs. Despite the enunciation of African socialism as the basis for government policy-making, aid inflows increased significantly during the period 1967-77, in both absolute terms and relative to other SSA [sub-Saharan countries] countries. The 'Socialist' vision of Mwalimu Nyerere's presidency excited widespread admiration and support from academics and policy makers in the capitalist West. (Mwase \& Ndulu 2008: 432)

And, reflecting the man of integrity that he was, Nyerere decided to step down, admitting that his policies had failed and that it was time for other ideas to be explored. He remained a figure of respect to the end of his life, a moral force in Tanzania. 


\section{KEEP THE BABY, THROW OUT THE BATHWATER: CONCLUDING THOUGHTS}

By the late 1970s the rise of Milton Friedman and monetarist economics and the leadership of the UK under Margaret Thatcher and the US under Ronald Regan signalled a major shift in Western economy policy. Clearly, all the African socialist policies of our four leaders failed. So what is worth salvaging from this episode of Africa's history? It is the vision of bold and broad transformative change that I find admirable and worthy of emulation, and the desire to lift entire populations out of poverty and give them a decent life, as evidenced by Nyerere's efforts. Although of the four regimes Nkrumah's was the most short-lived, the veteran Ghanaian politician Obed Yao Asamoah notes that no political leader had the bold imagination of Nkrumah when it came to economic development. He states that 'Nkrumah was in a hurry, and he had great ambition' (Asamoah 2014: 76). Many of Nkrumah's plans that he could not implement have been resuscitated under various subsequent governments in Ghana, and those that remain dormant excite the imagination. Nkrumah not only planned the Volta River Project and the Akosombo Dam, he made plans for two additional dams at Kpong and Bui. The Kpong dam was built under the Acheampong military regime (1972-78), and construction on the Bui dam was started by the Chinese under President Kufuor (2000-8) and completed under the government of the National Democratic Congress. It is worth noting that these were governments of different ideological persuasions. Nkrumah began to drill for oil in the Half-Assini area in the 1950s, and Ghana today has an oil-producing region in the westernmost half of the coastal seaboard. In 1962 Nkrumah persuaded the Russians to commit to building a railway from Kumasi to Ouagadougou, the capital of Burkina Faso. That project lies dormant, but its potential is enormous (Asamoah 2014: 74). To add value to agriculture, he established the cocoa-processing factory in Tema in 1963. Many newer highways have been built in Ghana and have deteriorated; the motorway he built to link Tema and Accra remains the best highway in Ghana.

Africa's population is set to double in 2050. Much of the mineral wealth being exploited now is expected to have been exhausted by then. Africa cannot feed itself, though it possesses the largest area of unfarmed arable land in the world. We need the bold and transformative vision of the likes of Nyerere and Nkrumah to ensure that come 2050 we do not find ourselves in the same predicament as on the eve of independence, when our new leaders, coming out of decades of repressive colonial economic policies, were faced with what appeared to be insurmountable challenges.

\section{REFERENCES}

Akyeampong, E, 2015. China in West Africa's Regional Development and Security Plans. African Development 40, 1-20.

Aryeetey, E \& Fosu, AK, 2008. Economic growth in Ghana, 1960-2000. In Ndulu, B, O’Connell, S, Azam, J-P, Bates, RH, Fosu, AK, Gunning, JW, \& Njinkeu, D (Eds), The Political Economy of Economic Growth in Africa 1960-2000 Vol. 2. Cambridge University Press, Cambridge, UK.

Asamoah, OY, 2014. The Political History of Ghana (1950-2013): The Experience of a Non-Conformist. AuthorHouse, Bloomington, IN.

Assensoh, AB, 1998. African Political Leadership: Jomo Kenyatta, Kwame Nkrumah, and Julius K. Nyerere. Krieger, Malabar, FL.

Austen, R, 1987. African Economic History: Internal Development and External Dependency. James Currey, London. 
Babu, AM, 1981. African Socialism or Socialist Africa? Zed Press, London.

Brockway, F, 1963. African Socialism. Bodley Head, London.

Davidson, B, 1983. Africa. TV documentary series, a collaboration between Channel 4, the Nigerian Television Authority, MBTV and RM Arts.

Doumbouya SF \& Camara, F, 2008. Explaining economic growth in Africa: The case of Guinea. In Ndulu, B, O’Connell, S, Azam, J-P, Bates, RH, Fosu, AK, Gunning, JW, \& Njinkeu, D (Eds), The Political Economy of Economic Growth in Africa 1960-2000 Vol. 2. Cambridge University Press, Cambridge, UK.

Friedland, WH \& Rosberg, CG (Eds), 1964. African Socialism. Stanford University Press, Palo Alto, CA.

Gilman, N, 2003. Mandarins of the Future: Modernization Theory in Cold War America. Johns Hopkins University Press, Baltimore, MD.

Kaba, L, 2017. Kwame Nkrumah and the Dream of African Unity. Diasporic Africa Press, New York.

Lal, P, 2015. African Socialism in Post-Colonial Tanzania: Between the Village and the World. Cambridge University Press, New York.

Lewis, WA, 1953. Report on industrialization and the Gold Coast. Government Printer, Accra.

Lewis, WA, 1954. Economic development with unlimited supplies of labour. The Manchester School 22, 139-191.

Meldrum, A, 1994. Three leaders of southern Africa. Africa Report, 39, 70-72.

Mohiddin, A, 1981. African Socialism in Two Countries. Croom Helm, London.

Muehlenbeck, PE, 2012. Betting on the Africans: John F. Kennedy’s Courting of African Nationalist Leaders. Oxford University Press, Oxford, UK.

Mwase, N \& Ndulu, BJ, 2008. Tanzania: Explaining four decades of episodic growth. In Ndulu, BJ, O’Connell, SA, Bates, RH, Collier, P \& Soludo, CC (Eds), The Political Economy of Economic Growth in Africa 1960-2000 Vol. 2. Cambridge University Press, Cambridge, UK.

Ndiaye, M, 2008. State control and poor economic growth performance. In Ndulu, BJ, O’Connell, SA, Bates, RH, Collier, P \& Soludo, CC (Eds), The Political Economy of Economic Growth in Africa 1960-2000 Vol. 2. Cambridge University Press, Cambridge, UK.

Ndulu, BJ, 2008. The evolution of global development paradigms and the influence on African economic growth. In Ndulu, BJ, O’Connell, SA, Bates, RH, Collier, P \& Soludo, CC (Eds), The Political Economy of Economic Growth in Africa 1960-2000 Vol. 1. Cambridge University Press, Cambridge, UK.

Nkrumah, K, 1970 [1964]. Consciencism. Modern Reader Paperbacks, New York and London.

Nyerere, JK, 1968. Ujamaa: Essays on Socialism. Oxford University Press, Dar es Salaam and London.

Nyerere, JK, 1977. The Arusha Declaration Ten Years Later. Government Printer, Dar es Salaam, United Republic of Tanzania.

Omaboe, EN, 1966. An introductory survey. In Birmingham, W, Neustadt, I \& Omaboe, EN (Eds), A Study of Contemporary Ghana: Vol. 1. The Economy of Ghana. George Allen and Unwin, London.

Onuoha, B, 1965. The Elements of African Socialism. André Deutsch, London. 
Rostow, WW, 1964. The Stages of Economic Growth: A Non-Communist Manifesto. Cambridge University Press, London.

Schmidt, E, 2007. Cold war and Decolonization in Guinea, 1946-1958. Ohio University Press, Athens, $\mathrm{OH}$.

Schmidt, E, 2013. Foreign Intervention in Africa: From the Cold War to the War on Terror Cambridge University Press, New York.

Scott, JC, 1998. Seeing like the State: How Certain Schemes to Improve the Human Condition have Failed. Yale University Press, New Haven, CT.

Sékou Touré, A, 1972. La révolution culturelle, troisième édition. SRO Kundig, Genève. Senghor, LS, 1964. On African Socialism. Translation and introduction by Mercer Cook. Praeger, New York.

Shivji, IG, 2010. The village in Mwalimu's thought and political practice. In Chachage, C \& Cassam, A (Eds), Africa's Liberation: The Legacy of Julius Nyerere, Pambazuka, Cape Town and Nairobi.

Tignor, RL, 2006. W. Arthur Lewis and the Birth of Development Economics. Princeton University Press, Princeton, NJ.

Williams, J, 2016. Pan-Africanism in Ghana: African Socialism, Neoliberalism, and Globalization. Carolina Academic Press, Durham, NC. 